\title{
URBAN REGENERATION ECONOMICS: THE CASE OF LISBON'S OLD DOWNTOWN
}

\section{Francisco Loforte RIBEIRO}

Instituto Superior Técnico, Departamento de Engenharia Civil e Arquitectura, Seç̧ão de Estruturas e Construção, Av. Rovisco Pais 1, 1049 Lisboa, Portugal E-mail: loforte@civil.ist.utl.pt

Received 5 July 2007; accepted 30 January 2008

\begin{abstract}
Buildings are one of the biggest assets of Lisbon's central downtown accumulated over a period of several centuries. The efficient use and optimization of the value of these assets are a challenge for both the owners of individual buildings and for society as a whole. Recently, a new regeneration initiative was announced for old urban Lisbon's downtown, covering three fields of intervention: the economic, social and physical fields. This paper presents a case study of the regeneration program for the Lisbon's old downtown including an analysis of the framework used to assess the costs and benefits.
\end{abstract}

KEYWORDS: Building; Cost-benefit analysis; Economic analysis; Urban renewal

\section{INTRODUCTION}

The physical and social degradation of central urban areas is a widespread problem in major European Union (EU) cities, and the causes are related to the abandoning of old urban spaces and a reduction of investment in their main assets (Urbeviva, 2007). The progressive deterioration of the old urban centers has been worsening and creating new social and economic problems. Therefore, more and more European cities are pursuing urban redevelopment projects in different areas of public intervention aimed at attracting people back into the city (Bianchini, 1999; Law, 2000; Balsas, 2001, 2004). Major urban renewal projects in urban central areas are justified by the public interest in restoring deteriorated architectural heritage (Couch et al., 2002). It is assumed, furthermore, that renewed historical sites contain distinctive architectural elements that confer prestige and a touch of distinction on city's image (Orueta, 2007).

In response to the dramatic physical deterioration of building assets and the rapid decline in occupancy in the central areas of Portugal's major cities, in 2004 the Portuguese government published the legal framework that regulates the creation and operation of the urban rehabilitation societies (RSRU, 2004). The mission of these societies is to develop and promote urban regeneration initiatives aimed at revitalising and regenerating the rundown central areas of Portugal's major cities.

Lisbon is the capital of Portugal. The city's central downtown built heritage, which dates from the seventeenth century, was rebuilt immediately after the 1755 earthquake. Lisbon's central downtown area has experienced dramatic physical degradation of its major built heritage in the last thirty years (Videira, 2006). In recent decades, the economic and so- 
cial profile of Lisbon's central downtown has changed; in particular, some economic activities have been given up and the urban functions have changed (CMLa, 2004). Therefore, pre-existing residential growth halted and occupancy fell dramatically as many individuals and families left the central downtown areas. One of such areas is the São Paulo community presented in this study.

More recently, the Lisbon's central downtown was declared a critical zone for public intervention by the local government authority (CMLb, 2004). Various initiatives have been used in the past in Lisbon, mostly concentrated on improving of the physical condition of residential buildings (Appleton, 2003). Recently, a new regeneration initiative for the old urban Lisbon's downtown was announced, covering three fields of intervention: the economic, social and physical fields (CBC, 2006).

The economic evaluation of regeneration and renewal interventions raises issues common to every cost efficiency analysis or cost benefit analysis of a major investment in building. In addition, the urban residential environment has good public characteristics in the sense that everyone could gain from joint action to improve an area since the benefits derived from housing renovation are substantially non-excludable (Balchin et al., 1992). Many households are likely to enjoy the external benefits of an improved environment and higher property values. Cost efficiency and cost benefit analyses have been widely recognized as a useful framework for assessing the positive and negative aspects of prospective actions and policies, and for making the alternatives economic implications an explicit part of the decision-making process (Arrow et al., 1996). However, studies and frameworks on the economic evaluation of the regeneration of old urban heritage are limited (Orueta, 2007). This paper presents a case study of the regeneration program for the Lisbon old downtown including an analysis of the framework used to assess the costs and benefits.

\section{METHODOLOGY OVERVIEW}

Encouraged by the shortage of economic studies on urban regeneration and renewal programs and the approaches for cost-benefit analysis, this paper sets out to give a detailed presentation of the approach used to evaluate a proposed multi-field intervention in Lisbon's old downtown.

The methodology proposed in this paper is aimed at helping in the practical application of economic evaluation methods in urban regeneration and renewal. It can also be viewed as an approach to the reliable preliminary screening of projects, which may subsequently be appraised in more detail.

The contents and conclusions of the research work were arrived at by means of: (i) a review of publications and State-Of-The-Art practices related to urban regeneration; (ii) a review of data and information on past public interventions; (iii) a survey conducted throughout the duration of the study; and (iv) a case study. The study estimated the costs benefits of the regeneration intervention planned for the São Paulo community. The framework used in this study is being extended to other run-down areas of Lisbon's old downtown.

\section{PUBLIC INTERVENTION}

Major urban regeneration interventions are justified by the public interest in recovering obsolete architectural heritage (Couch et al., 2002). One of the most significant events for the urban regeneration of Portuga's major cities was decree no. 104/200 of $7^{\text {th }}$ May 2004 which provides the legal framework for creating public enterprises, known as Sociedades de Reabilitação Urbana (SRUs) (Urban Regeneration Enterprises) (RSRU, 2004). Sociedades de Reabilitação Urbana (SRUs) have been promoted by the government and established by municipalities, in order to achieve a focused, integrated regeneration strategy for 
major cities. They produce a coherent single enterprise for the future of their entire area and then co-ordinate its implementation as to deal with the urban regeneration operation in central urban areas. The main aim of these local SRUs is to promote urban rehabilitation of the built heritage operations within their intervention area. The agencies are separate public legal enterprises. They seek to achieve the harmonious physical regeneration of their areas by implementing their strategic plan in a way that would not be possible with individual ad hoc decisions.

The Lisbon municipality attempted to deal with the degradation of the old central areas by creating three public enterprises responsible for the physical rehabilitation of the historic district. They are: the SRUBP - Sociedade de Reabilitação Urbana da Baixa Pombalina; the SRULO - Sociedade de Reabilitação Urbana da Lisboa Ocidental; and the SRUO Sociedade de Reabilitação Urbana da Lisboa Oriental. The public intervention in urban regeneration follows a 'top-down' planning approach supported by four nation wide programmes:

a) Recria: which looks at the rehabilitation of rented private housing. It provides a set of financial incentives for private owners to restore and renovate housing units building in a poor state of repair. Therefore, the programme aimed at providing financial support for renovation and rehabilitation works in two ways: grants and mortgage loans. Mortgage loans are used for fund the renovation work not covered by grants.

b) Rehabita: which extends the Recria programme by including financial incentives for regeneration initiatives in historic districts classified as critical zones for public intervention and which are bound by the planning directives. It also provides financial support to municipalities willing to rehabilitate the built heritage in historic districts. c) Recriph: which is a special programme similar to the Recria which combines grants and mortgage loans to finance renovation works in old buildings developed under a horizontal property regime.

d) Solarh: which provides financial support in the form of mortgage loans at zero interest to owners with low income to allow them to carry out the renovation works needed to rehabilitate their homes. It also provides financial support to non-governmental social solidarity organizations.

In addition, the Lisbon's municipality recently launched an additional program called Programa LX - Reabilitar o Centro. This programme has three aims: (i) to rent housing and retail units in improved buildings owned by the municipality at $75 \%$ of the rental market value; (ii) to attract new residents, mainly for a young population studying and working in Lisbon; and (iii) restore economic and cultural activity, mainly retail and entertainment to attract peoples back into the city. The rental contract duration for all types of renting is five years.

The targeting of public resources in urban regeneration in order to maximise the leverage of private sector investment is at the heart of these five government programmes.

\section{ECONOMIC EVALUATION TECHNIQUES}

There are three basic techniques that can be used for the economic analysis of urban regeneration and renewal programs. In increasing order of complexity they are: cost-effectiveness analysis; weighted cost-effectiveness analysis (sometimes referred as to cost-utility analysis); and cost-benefit analysis.

Cost-benefit analysis is appropriate for projects whose benefits are measurable in monetary terms and whose output has a market price that is relatively easy to assess (EU, 2002). 
Cost-effectiveness analysis and weighted cost-effectiveness analysis can be used for comparing projects whose benefits are not readily measurable in monetary terms (Levin, 1983). The main difference between the techniques is in the measurement of benefits. The choice of technique depends on the nature of the project, time constraints and the information available.

Cost-effectiveness analysis and weighted cost-effectiveness analysis are used to compare alternatives that are equally effective in achieving a stated goal or standard (Needleman 1969; Ruegg and Marshal, 1990; Balchin et al., 1992; Levin, 1993; Fukahori and Kubota, 2003; Kirk et al., 2004). Both analysis concentrate on the minimisation of cost subject to the provision of a given goal or standard. These approaches have focused on the choice between the renovation of old building stock and redevelopment. Several researchers have formulated and refined the mathematical expressions for comparing reconstruction and renovation. Needleman (1969) introduced the basic method with emphasis on the purely financial viewpoint of the agency responsible for housing redevelopment.

Cost-benefit analysis has been widely used to support the decision-making process in urban projects (Tudela et al., 2006). It differs from cost-effectiveness analysis in that benefits are, as far as possible, expressed in monetary terms and hence are directly comparable with one another. Cost-benefit analysis is the methodology best equipped to provide in-depth comprehensive quantification and evaluation of urban regeneration and renewal interventions (Schofield, 1987; Henket, 1990; Stubbs, 1998; Brennan et al., 2001; Morisugi and Ohno, 2003; Johnson, 2006; Gao and Asami, 2007).

Cost benefit analysis provides a consistent basis for comparing alternative investments within sectors and across sectors (Castillo, 1998). In addition, it strives to demonstrate that the project's investment will generate suf- ficient benefits to offset the cost of the investment and its risk. Cost-benefit analysis can be used from the standpoint of owner-occupant, owner-investor and owner-developer (Ruegg and Marshall, 1990).

There are three types of cost-benefit analysis that can be used to asses the value of investment operations: (i) financial analysis; (ii) economic analysis; and (iii) social analysis (Belli et al. 1997). Financial analysis looks at the project from the perspective of the implementing agency: it identifies the project's net money flow to the implementing entity and assesses the entity's ability to meet its financial obligations and to finance future investments. Economic analysis, by contrast, looks at a project from the perspective of the entire country and measures the effects of the project on the economy as a whole. Social analysis extends the economic analysis to include the redistribution effects. Financial analysis is appropriate for projects whose benefits and costs are measurable in monetary terms and whose output has an assessable market price. Economic analysis is similar in form to financial analysis in that both assess the value of the project.

Urban renewal projects may have many components, some with benefits measurable in monetary terms and some with single or multiples benefits that are not measurable in monetary terms (Schofield, 1987; Rosenfeld and Shohet, 1999; ODPM, 2004; CMHC, 2005). Therefore, the three basic techniques can be used to assess urban regeneration and renewal programs. However, cost-benefit analysis makes it possible to calculate project's Net Present Value (NPV), which provides a better measure of its value, not only for both the implementing agency and the country. Ray (1984) indicates that for projects whose benefits are measurable in monetary terms, the criterion for project acceptability is the expected Net Present Value (NPV). In particular, the criterion requires that the expected NPV (i) must 
not be negative, and (ii) must be at least as high as those of other mutually exclusive alternatives.

For urban renewal projects, the analyst needs to define the objectives of the analysis and the alternatives to be evaluated, including the without-project alternative.

\section{THE SÃO PAULO COMMUNITY CASE}

The São Paulo community is located in the heart Lisbon's downtown area. It is a heterogeneous and varied space characterized by historic building, narrows streets and squares. São Paulo community was particularly hard hit by occupancy rates in some buildings, loss of residents, population aging and economic and social problems.

The occupancy rate fell from $82 \%$ in 1991 to $55 \%$ in 2001 (INEa, 2003). Between 1991 and 2001 , the community lost $33 \%$ of its residents (INEb, 2003), while $75 \%$ of residents were more than 24 years old in 2001 (INEb, 2003). The employment rate was $30 \%$ in 2001 and, in the same year, $22 \%$ of residents had no education (INEb, 2003). Rented occupation was predominant in 2001 (86\%) (INEa, 2003). This situation created a downward spiral of physical decline of the community's built heritage and of social and economic degradation.

Despite the degradation problems, the São Paulo community has great appeal and market potential, largely thanks to its strategic location, the historic and architectural heritage, the building assets and the economic activities that justify a regeneration intervention aimed at attracting people and business. The municipality attempted to deal with this problem in 2005 by creating and putting in place a public enterprise responsible for the physical and social regeneration of the Lisbon's downtown area, SRUBP - Sociedade de Reabilitação da Baixa Pombalina. The intervention of the SRUBP is justified by four main reasons (RSRU, 2004):
- Structural reasons: the loss of functionality due to aging property, the lack of social amenities, and traffic and parking difficulties.

- Economic reasons: the possibility of attracting private investments in building renovation, making capital gains from higher housing rents, creating new business opportunities.

- Social reasons: the possibility of creating employment, social rehabilitation and attracting young families and tenants.

- Cultural reasons: The possibility of intensifying the use of the downtown area during trading hours and extend it into the night, to promote the organization of quality cultural events.

The intervention envisaged by the SRUBP for the São Paulo community has been incorporated into the urban planning program for the city of Lisbon (PDML, 2002). The SRUBP is seeking the economic and financial participation of private agents in the rehabilitation of the urban built heritage and the social and economic regeneration of the São Paulo Community.

The studied area comprises thirty eight buildings, organized into nine blocks, and 370 housing units (Figure 1). A survey of the state of repair of the built heritage was conducted, along with an inquiry of the households and tenants, as part of this study. The state of repair survey found that $29 \%$ of the study area was deemed to be bad or very bad condition (Figures 2 and 3). Of the building stock in the study area, $24 \%$ is classified as historic buildings and $13 \%$ is classified as building of public interest. Seventy-six percent of the building stock is privately owned. Housing is the predominant occupation (40\%) followed by restaurants (19\%) and offices (18\%). Thirtytwo percent of the housing units were vacant (Figure 3). 


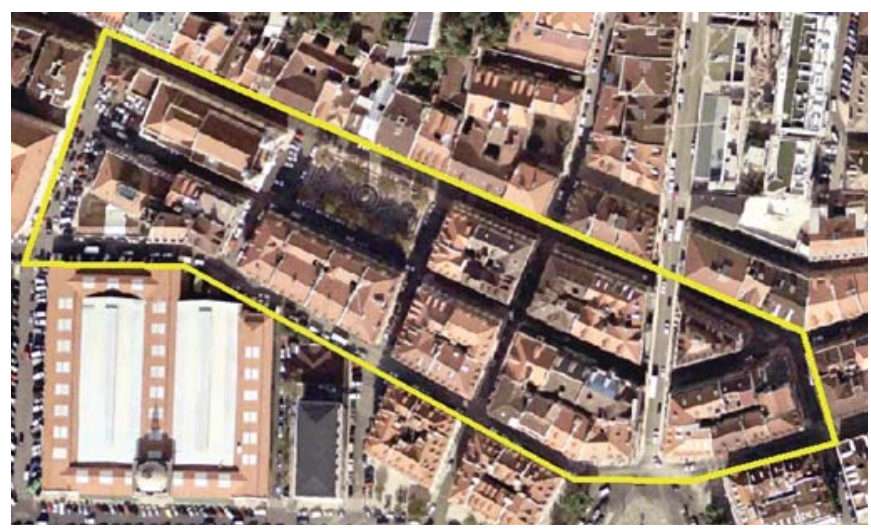

Figure 1. Study area marked by yellow line

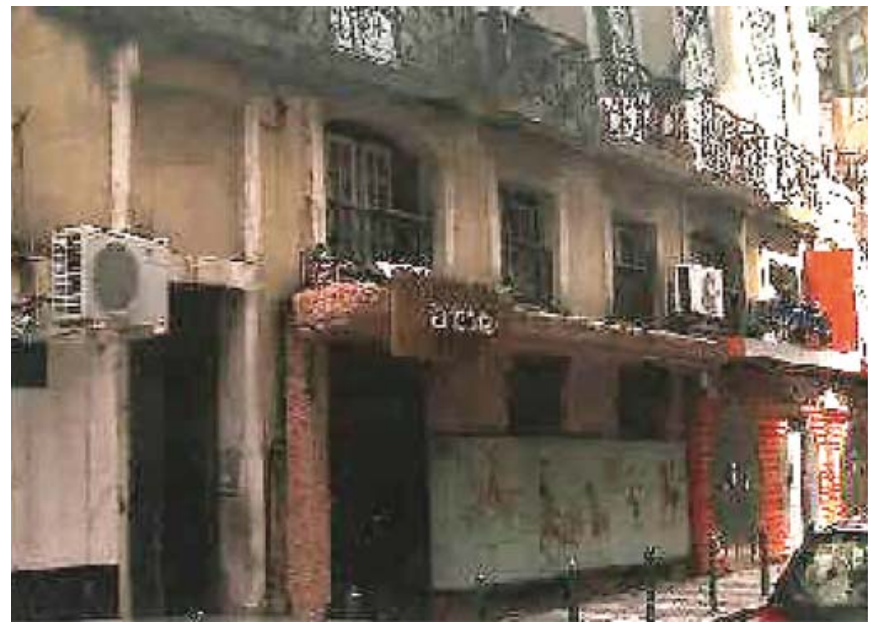

Figure 2. Condition of a building

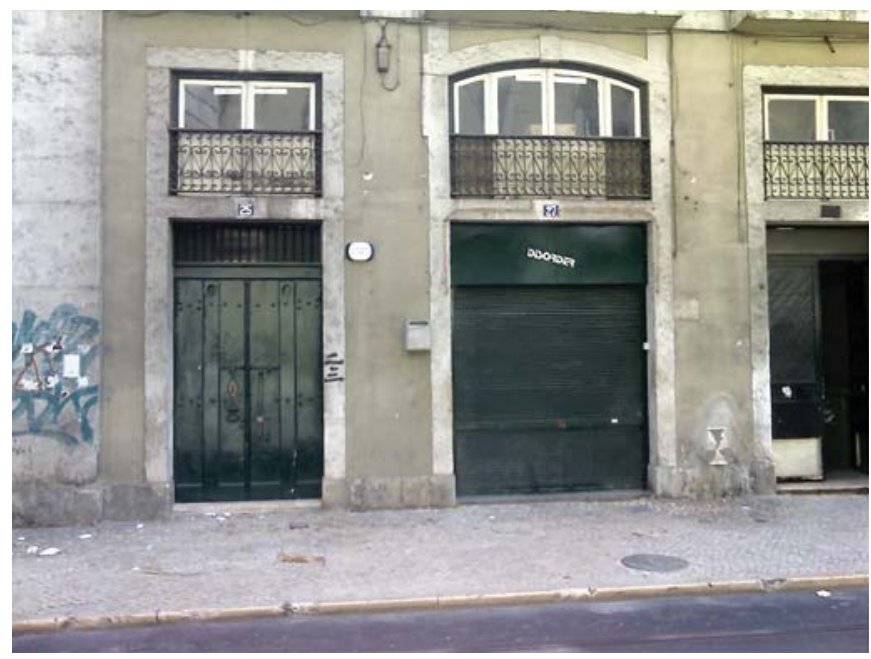

Figure 3. View of a vacant building 
Based on the survey, four main areas of intervention for the São Paulo community were considered by the SRUBP: (i) rehabilitation of the building assets in order to regain residents; (ii) the upgrading of public spaces including parking, infrastructures, urban furniture, public transport, mobility and traffic signs; (iii) the upgrading and construction of public facilities as an attraction factor; (iv) commercial revitalization and creation of new jobs.

A detailed intervention plan for the studied area was prepared based on the criteria established in the PDML (2002).

\section{IDENTIFYING BENEFITS AND COSTS OF THE PROJECT}

A major barrier to analysing urban regeneration programs is compiling and presenting the economic information in ways that will help the implementing agency decide if the program would make economic sense.

The economic rationale of public investment decisions as to whether a project should be implemented, or which projects should be selected subject to a given budget constraint, requires identifying and measuring the benefits and costs during the life of the project and calculating the net present value (NPV) of this flow of net benefits.

The choice of economic evaluation tools to assess urban regeneration programs depends on the nature of the intervention in question and on its stated objectives. Cost-benefit analyses of urban renewal projects generally include an assessment of the project benefits compared with the estimated cost of the project. All consequences of the programme need to be identified and measured in monetary terms (Mishan, 1994; Peterson and Larsen, 2006). Therefore, an important step in cost-benefit analysis is the identification and quantification of a project's costs and benefits. Table 1 summarizes the major benefits and cost cate- gories of the project from the perspective of the implementing agency, the SURBC.

The major benefits of the regeneration program are those of sales and rentals after project completion, better living standard and environment for present and future residents and lower social costs, especially in relation to employment and economic and cultural growth. In addition, the regeneration intervention may be expected to enhance the value of the São Paulo community's property because the regenerated site will create economic and cultural development which would otherwise have occurred elsewhere in the city.

The major expenses of the regeneration program are those related to property costs, improvement costs, tenants' relocation costs and forgone rent revenue.

Table 1. Benefits and costs

\begin{tabular}{ll}
\hline Benefits & Costs \\
\hline $\begin{array}{l}\text { Asset sales and } \\
\text { rentals }\end{array}$ & $\begin{array}{l}\text { Opportunity costs } \\
\text { of property }\end{array}$ \\
Lower social cost & Improvement costs \\
$\begin{array}{l}\text { Better living } \\
\text { environment }\end{array}$ & Tenants relocation costs \\
& Forgone revenue \\
\hline
\end{tabular}

\section{ESTIMATING BENEFITS AND COSTS OF THE URBAN RENOVATION PROJECT}

In order to incorporate the effects of the project into a cost-benefit framework it is necessary both to measure and compare them over a common denominator. An economic assessment should consider the total value of benefits received compared to the total costs incurred in the project. Therefore, in this section we offer a discussion of how project benefits and cost were measure and valued for the cost-benefit analysis. 


\subsection{Benefits}

Benefits are those effects that accrue to the SRUBP which include: (i) asset sales after improvements; (ii) asset rentals after improvements and (iii) lower social costs. Revenue from asset sales in the present study comes from the estimated investment value of the individual property after the improvements. The property investment value was determined using the basic formula (1) established in the municipal tax code (CIMI, 2003) which represents a reasonable estimate of the economic price for the existing properties.

$$
V_{t}=V_{c} \times A \times C_{a} \times C_{1} \times C_{q} \times C_{v}
$$

where: $V_{t}=$ Investment Value; $V_{c}=$ Base cost per sq. m.; $A=$ Gross floor area plus the area surplus to the enclosure; $C_{a}=$ coefficient of use; $C_{1}=$ coefficient of location; $C_{q}=$ coefficient of quality and comfort; $C_{v}=$ coefficient of age.

The base cost per sq. m. is updated every year by Portugal's Ministry of Finance and it is based on the annual cost index. Revenue from asset rentals is given by the estimated rental value in use of the individual property after the improvements. A regression analysis based on the present rental values stored in the database of the São Paulo community was carried out in order to estimate the rental vsalue in use after the improvements. The lower social costs were measured by the unemployment benefit savings which accrue due to the number of jobs created after the project completion. It is expected that 67 new jobs will be created with the regeneration programme.

\subsection{Costs}

The projects costs are those relevant to the agency that undertakes the project. They include the cost of land and building assets, intervention improvement costs, tenants' relocation costs and rent revenue forgone.
The value of the opportunity cost of the land and existing building assets, as they stand before the intervention, was valued using the formula (1). It gives the estimated investment value. The improvement costs include the costs of renovating the building assets and the upgrade and construction costs of public spaces and urban facilities. Tenant relocation costs included expenses incurred with tenant compensation. Improvement costs, upgrade and construction costs of public space and urban facilities and tenant relocation costs were valued at market prices. Revenue forgone is the income lost from rentals.

Table 2 presents the costs and benefits figures for the regeneration programme for the studied area.

Table 2. Cost and benefits

\begin{tabular}{ll}
\hline Costs and Benefits & Amount \\
\hline Cost & \\
Opportunity cost of property & $63,052,676.00 €$ \\
Improvement costs & $14,325,895,98 €$ \\
Tenant relocation & $276,687.00 €$ \\
Forgone revenue & $13,000.00 €$ \\
Benefits & \\
Sales and rentals & $87,280,385.00 €$ \\
Lower social cost & $552,000.00 €$ \\
Better living environment & not measured \\
\hline
\end{tabular}

\section{ECONOMICS OF THE STUDIED AREA}

The cost-benefit analysis requires the identification of a baseline or status quo scenario, against which the costs and benefits of alternative project interventions are assessed (Moran and Sherrington, 2006). A CBA compares alternatives over time as well as space, and uses discounting to summarize its findings into a measure of net present value (NPV) (Hanley and Spash, 1993). An essential element in 
evaluating the economic benefits of a project is the definition of an alternative to the project, the 'without project' scenario. What would happen to existing built heritage? In the case of regeneration programmes, which involve bringing existing built assets back into normal operating conditions, the without project scenario would be that no further investments are made and that the built assets will continue to degrade further.

A cost-benefit analysis of the project was carried out for the studied area. It is based on cash-flow analysis of the two categories of cash-flows of the project:

1) the operational cash-flows: cash received or expended as a result of the intervention activities during the operational phase;

2) the investment cash-flows: cash received or expended through capital expenditure, investments and acquisitions;

The cash likely to be generated by the project is estimated for every period during the expected life and the cash likely to be needed to develop and sustain the project is then subtracted. The net cash flows are included in the economic profile of the regeneration program.

According to the EU Guide to CBA (1997 the analysis of NPV is a standard method for assessing the present value of competing alternatives over time. The time dimension is very important in counterbalancing costs and benefits. This is because a project requires a high capital investment in the first months and provides benefits over a long time period. This means it is necessary to calculate the present value of all cost and benefit effects by using a suitable discount rate. The discount rate used in this study is $3.5 \%$. The NPV found for the regeneration program is positive, which means that the intervention is worthwhile for the implementing agency. In addition, it is expected to increase the number of residents with 275 new residents coming to the São Paulo community.

\section{CONCLUSION}

Cost-benefit analysis has been widely accepted as an appropriate tool for appraising regeneration and renewal programs. It may be true as well that a project for which the economic analysis is good or excellent will be easier to implement and will tend to be given a higher rating for the expected achievement of development objective, both during project supervision and after project completion.

Analysis of the economic effects of urban regeneration and renewal initiatives or strategies is an useful tool for assessing planning policies and decisions in central urban areas. The economic evaluation of regeneration and renewal raises issues common to every cost efficiency analysis or cost benefit analysis of a major investment in building. This paper describes the regeneration framework established in Portugal for old urban areas. It outlines a framework to assess the costs and benefits of urban regeneration. The case study identifies the main cost and benefits of the S. Paulo Community in Lisbon's downtown. This paper shows that urban regeneration can help to reverse the current state of physical degradation prevailing in the built heritage and to regenerate economic activity in the central areas of major cities.

\section{REFERENCES}

Appleton, J. (2003) Jornadas a Baixa pombalina e a sua importância para o património mundial [The pombalina downtown and its importance to the world heritage]. CML - Pelouro de Licenciamento Urbanístico e Reabilitação Urbana. CML. (In Portuguese)

Arrow, K.J., Cropper, M.L., Eads, G.C., Hahn, R.W., Lave, L.B., Noll, R.G., Portney, P.R., Russell, M., Schmalensee, R., Smith, V.K. and Stavins, R.N. (1996) Is there a role for benefit-cost analysis in environmental, health, and safety regulation? Science, 272(5259), Issue of 12 April 1996, pp. 221-222. 
Balchin, P.N., Kieve, J.L. and Bull, G.H. (1992) Urban Land Economics and Public Policy, $4^{\text {th }}$ Edition, Macmillan.

Balsas, C. (2001) Commerce and the European city center: Modernization, regeneration and management, European Planning Studies, 9(5), pp. 677-682.

Balsas, C.J.L. (2004) City centre regeneration in the context of the 2001 European capital of culture in Porto, Portugal, Local Economy, 19(4), pp. 396-410.

Belli, P., Anderson, J., Barnum, H., Dixon, J. and Tan, J. (2001) Economic Analysis of Investment Operations, Analytical Tools and Practical Applications, WBI, World Bank, Washington D.C., USA.

Bianchini, F. (1999) Cultural learning for urban sustainability. In: Nystrom, L. (ed.) City and culture: Cultural processes and urban sustainability. Stockholm: The Swedish Urban Environment Council, pp. 34-51.

Brennan, A., Rodes, J., Tyler, P. and Warnock, C. (2001) Neighbourhood Regeneration: Lessons and Evaluation Evidence from 10 SRB case studies: Mid-Term Report, Department of Land Economy, Cambridge, UK.

Castilho, C.P. (1998) Economic Analysis of Social Investment Fund Projects, World Bank Report, LCSHD, Washington D.C., USA.

CBC (2006) Proposta de Revitalização da BaixaChiado [Regeneration proposal for old downtown]. Comissariado da Baixa-Chiado.

Chatel, V. and Soulet, M.H. (2003) An EvaluationTool of Social Re-Integration Programs: The Analytical Evaluation. Fribourg University, Fribourg.

CIMI (2003) Código do Imposto Municipal sobre Imóveis [Property Tax Code], D-L No. 287/2003 de 12 Novembro, Diário da República, Portugal. (In Portuguese)

CMHC (2005) A Framework for Cost-Benefit Analysis of HASI and RRAP-D, Socio-economic series, 05-038, CMHC, Canada.

CML (2004a) Planeamento, Diagnóstico Económico e Competitividade Urbana de Lisboa, Licenciamento Urbanístico e Planeamento Urbano [Planning, Economic Assessement and Urban Competitiveness, Urban Licensing], Colecção de Estudos Brancos, Lisboa XX1, 2. (In Portuguese)
CML (2004b) Planeamento e Diagnóstico Sócio-Urbanístico da Cidade de Lisboa, Licenciamento Urbanístico e Planeamento Urbano [Planning and Economic Assessement of Lisbon, Urban Licensing], Colecção de Estudos Brancos, Lisboa XX1, 4. (In Portuguese)

Couch, C. and Perch, S. (eds.) (2002) Urban Regeneration in Europe. Oxford: Blackwell.

EU (2002) Guide to Cost-benefit Analysis of Investment Projects. [Online] European Commission. Available at: http://ec.europa.eu/regional_policy/ sources/docgener/guides/cost/guide02_en.pdf.

Fukahori, K. and Kubota, Y. (2003) The role of design elements on the cost-effectiveness of streetscape improvement, Landscape and Urban Planning, 63(2) pp. 75-91.

Gao, X. and Asami, Y. (2007) Influence of lot size and shape on redevelopment projects, Land Use Policy, 24(1), pp. 212-222.

Hanley, N. and Spash, C. (1993) Cost-benefit Analysis and the Environment. Edward Elger, England.

Henket, A.J. (1990) Choosing an Appropriate Intervention in Existing Building: A Theoretical Model. In: Kiang, Q.L. (ed.) Proc. of the International Symposium on Property Management and Modernization, 7-9, Singapore, pp. 473-482.

INE (2003a) XIV Recenseamento Geral da População IV Recenseamento Geral da Habitação Censos 2001. Resultados Definitivos [General Population Census, 2001 - Final Results]. Região de Lisboa e Vale do Tejo. Lisbon, INE. (In Portuguese)

INE (2003b) XIV Recenseamento da População e da Habitação (Portugal) - Censos 1991. Resultados Definitivos [General Population Census, 1999 Final Results]. Região de Lisboa e Vale do Tejo. Lisboa, INE. (In Portuguese)

Johnson, M.P. (2006) Single-period location models for subsidized housing: Project-based subsidies, Socio-Economic Planning Sciences, 40(4), pp. 249-274.

Kirk, J.A., Wise, W.R. and Delfino, J.J. (2004) Water budget and cost-effectiveness analysis of wetland restoration alternatives: a case study of Levy Prairie, Alachua County, Florida, Ecological Engineering, 22(1), pp. 43-60.

Law, C. (2000) Regenerating the city centre through leisure and tourism, Built Environment, 26(2), pp. 117-129. 
Levin, H.M. (1983) Cost Effectiveness Analysis: A Primer. Sage Production, Beverly Hills.

Mishan, E.J. (1994) Cost-benefit Analysis: An Informal Introduction. $4^{\text {th }}$ edition, London: Rutledge.

Moran, D. and Sherrington, C. (2007) An economic assessment of windfarm power generation in Scotland including externalities, Energy Policy, 35(5), pp. 2811-2825.

Morisugi, H. and Ohno, E. (1995) Proposal of a benefit incidence matrix for urban development projects, Regional Science and Urban Economics, 25(4), pp. 461-481.

Needleman, L. (1969) The comparative economics of improvement and new building, Urban Studies, 6(2), pp. 196-209.

ODPM (2004) Assessing the Impacts of Spatial Interventions: Regeneration, Renewal and Regional Development 'The 3Rs guidance'. Office of the Deputy Prime Minister: London.

Orueta, F.D. (2007) Madrid: Urban regeneration projects and social mobilization, Cities, 24(3), pp. 183-193.

PDML (2002) Plano Director Municipal de Lisboa [Lisbon Master Plan], Resolução do Conselho de Ministros. (In Portuguese)

Petersen, M.L. and Larsen, T. (2006) Cost-benefit analyses of radon mitigation projects, Journal of Environmental Management, 81(1), pp. 19-26.

Ray, A. (1984) Cost Benefit Analysis: Issues and Methodologies. The John Hopkins University Press, Baltimore.
Rosenfeld, Y. and Shohet, I.M. (1999) Decision support model for semi-automated selection of renovation alternatives, Automation in Construction, 8(4), pp. 503-510.

RSRU (2004) Regulamento das Sociedades de Reabilitação Urbana DL No. 104/2004 [Urban Regeneration Societies Code], Diário da República, Portugal. (In Portuguese)

Ruegg, R.T. and Marshal, H.E. (1990) Building Economics: Theory and Practice. Van Nostrand Reinhold, New York, USA.

Schofield, J.A. (1987) Cost-Benefit Analysis in Urban \& Regional Planning. UNWIN HYMAN, London.

Stubbs, J. and Hardy, M. (2000) Evaluation of Three Neighbourhood Renewal Strategies. NSW, Australia.

Tudela, A., Akiki, N. and Cisternas, R. (2006) Comparing the output of cost benefit and multi-criteria analysis: An application to urban transport investments, Transportation Research Part A-Policy and Practice, 40(5), pp. 414-423.

Urbeviva (2007) Special Report: Knowledge Sharing on Previous Urban Development Experiences and Good Practice. [Online] Available at: www.urbeviva.net.

Videira, S.I. (2006) Analise Custo Benefício do Projecto de Reabilitação Urbana da Zona de São Paulo [Cost-Benefit Analysis of São Paulo Community]. MSc dissertation, Instituto Superior Técnico, Portugal. (In Portuguese)

\section{SANTRAUKA}

\section{MIESTU ATGAIVINIMO EKONOMIKA: SENOJO LISABONOS KOMERCINIO RAJONO ATVEJIS}

\section{Francisco Loforte RIBEIRO}

Pastatai - tai vienas pagrindinių Lisabonos centrinio komercinio rajono turtų, sukauptu per keletą amžiu. Efektyvus šio turto naudojimas ir vertès optimizavimas - tai iššūkis ir atskirų pastatų savininkams, ir visai visuomenei. Neseniai paskelbta nauja senojo Lisabonos komercinio rajono atgaivinimo iniciatyva, apimanti tris intervencijos sritis: ekonominę, socialinę ir fizinę. Šiame darbe pristatomas senojo Lisabonos komercinio rajono atgaivinimo programos atvejo tyrimas, pateikiama sąnaudu bei naudingumo įvertinimo sistemos analizè. 